\title{
Impacts of community based fisheries management (CBFM) on the livelihood of fishers at Sherudanga beel in Rangpur District, Bangladesh
}

\author{
Mst Kaniz Fatema ${ }^{1 \star}$, Jannatun Nahar ${ }^{1}$, Motia Gulshan Ara', Jannatul Fatema ${ }^{2}$ and Muhammad \\ Shahidul Haq ${ }^{1}$
}

${ }^{1}$ Department of Fisheries Management, Bangladesh Agricultural University, Mymensingh-2202.

2Department of Agricultural Economics, Bangladesh Agricultural University, Mymensingh-2202.

*Corresponding author. Email: kanizfatemafm@bau.edu.bd, kanizhossain@gmail.com

Copyright @ 2016 Fatema et al. This article remains permanently open access under the terms of the Creative Commons Attribution License 4.0, which permits unrestricted use, distribution, and reproduction in any medium, provided the original work is properly cited.

Received 26th January, 2016; Accepted 13th March, 2016

\begin{abstract}
Community Based Fisheries Management (CBFM) approach appears to be an important factor in managing fisheries successfully. Thus, this study aims to investigate and evaluate the fisheries management practices and its impact on the livelihood of the fisheries community of Sherudanga beel in Rangpur district (Bangladesh) for a period of 12 months, from March 2010 to February 2011. The study was conducted based on Community Based Fisheries Management (CBFM) practices, beel biodiversity, fish production, socio-economic and livelihood condition of the fishermen community. The studied beel is 83 acre seasonal floodplain, which was mainly used by a community consisting of 80 families for their livelihood, where the CBFM approach was introduced by the community. At pre-CBFM, there was no controlled management system from any NGO or even Government for the proper management of the beel. Recently, community fishers leased out this beel from the government in year 2000 for 12 years and started to manage it. The CBFM project works for the development of fishery system, the fishermen community and the general society. The yearly gross fish production was higher than pre-CBFM period, implying that average abundance and fish biodiversity were significantly higher in the CBFM implemented beel. Majority of the fishermen had primary level education (37.5\%) compared to $27.5 \%$ and $16.5 \%$ having secondary level and above secondary level education respectively, while $18.75 \%$ of them could sign their name only, indicating the improvement of education level among fishers. About $43.75 \%$ of them had small size family, while $40.0 \%$ and $16.25 \%$ had middle and large size families respectively. The prevalence of unconstructed house was the highest $(77.5 \%)$ while few of them $(22.5 \%)$ had semi constructed house. About $68.75 \%$ of the fishermen had medium income, while $12.5 \%$ and $18.75 \%$ had small and large income respectively. More than half $(56.25 \%)$ of the fishermen received credits from different sources while rest $(43.75 \%)$ of them did not get any credits. In conclusion, the overall findings showed that community based fisheries management has significantly increased annual fish production, lifted household income levels, improved access to credit from a wide range of sources and enabled livelihood diversification.
\end{abstract}

Key words: Beel, CBFM, fisheries, livelihood.

\section{INTRODUCTION}

Although fisheries management in inland open water bodies of Bangladesh is critical but attention in recent years has received on Community Based Fisheries Management (CBFM) to empower fishing communities and improving the sustainability of management of inland water bodies. Full participation of the local communities living in the beel area has been recognized to be a prerequisite for the successful implementation of any fisheries development programs. CBFM is an alternative management scheme that is based on a participatory 
approach and calls for direct involvement and contribution of the community into the management of local fisheries resources. Thus, Community Based Fisheries Management (CBFM) has become a common strategy for managing open water bodies and empowering local communities by involving community stakeholders, recognizing local needs, using local knowledge and establishing common property regiment (Berkes et al. 1998; Ostrom, 1990; Pomeroy and Berkes, 1997). It is a process by which people themselves have responsibility to manage their own resources, define their own needs, goals and aspirations and make decisions affecting their socio-economic welfare where government most often plays a minor role (Sajise, 1995). It also offers an opportunity to develop conservation approaches at local level and shift towards more sustainable fisheries and surroundding communities. As a result, CBFM has secured fisheries access for poor fisher's community and improved nutrition, health, education, social status, standard of housing and sanitation of fisher communities. In a word, a possible solution to empowering fishing communities and improving the sustainability of management is Community Based Fisheries Management (CBFM).

Among the vast inland fishery resources of Bangladesh, beels are more potential for fish production. The beel is considered as biologically sensitive habitats as they play a vital role in the recruitment of fish populations in the riverine ecosystems and provide nursery grounds for commercially important fishes. Beel is an important source of cheap animal protein for the local population and also provides opportunities of full and part-time employment for the traditional fish farming communities living in the vicinity of the beel, providing them with additional household income and animal protein supplements. But, this beel fishery has been continuing degradations in the recent years due to roads, embankments, drainage, flood control and natural siltation along with overfishing (Ali, 1997; Haque et al. 1999).

Sherudanga beel is located in Mithapukur upazila of Rangpur district, Bangladesh covering rich reserve of aquatic fauna. This would provide great potential for the development of beel fisheries if appropriate management measures are carefully taken. Conventional fisheries management has not been effective for the beel thus CBFM approach has been introduced in 2000 and community has formed consisting of 80 families. CBFM aims to involve the participation of community stakeholders to ensure that future generations of Sherudanga beel will continue to have access to the benefits associated with sustainable fisheries and healthy ecosystems. Due to well-developed community involved in the beel for their livelihood, socio-economic condition of the fishermen, fisheries status, geographical situation and beelstructure, the Sherudanga has been identified as the most important and promising area for freshwater fish culture for this study.

However, published research works on the socioeconomic condition of fishermen and management aspects of CBFM in the Sherudanga beel are relatively scanty. Therefore, a great requirement in socio-economic studies of fishermen livelihood concentrating on the development of CBFM models for effective management of Sherudanga beel is needed. This paper explored the role of existing institutional structures and types of organizations that directly affected the management of fisheries as well as discusses the impacts of CBFM on the livelihood of the fishermen. In addition, this study also examined the existing status of fish composition and fish production; to assess the diversity of fish and other aquatic species; and to make recommendations for the policy guidelines for the future development of the fishermen. We think, this study would be used for further studies as baseline information for developing appropriate fisheries managements for Sherudanga beel.

Considering the importance of fish biodiversity for sustainable management of beel fisheries, an assessment was made of the present management system of the fisheries in the Sherudanga beel to investigate the existing potentials of the local communities to be involved in and to participate in the development of a community-based fisheries management system on beneficiary's livelihood of the said beel.

\section{MATERIALS AND METHODS}

\section{Study Area}

The study was conducted in Sherudanga beel situated in the northern part of Bangladesh under Mithapukur upazila of Rangpur district (Figure 1 and 2). The area of the beel is about 83 acres, while it becomes about 500 acres during rainy season. The beel is located in Mithapukur upazila of Rangpur district, Bangladesh. Its geographical coordinates are $25^{\circ} 34^{\prime} 30^{\prime \prime}$ North, $89^{\circ} 16^{\prime}$ $00^{\prime \prime}$ East. There are several beels are scattered in this upazila including Chatra beel, Salinir beel, Chaitali beel, Boro Phaliar beel, Boro ruher beel, 26-bigha Dubla Chori beel, Tulshi Danga beel and Sherudanga beel. Among them, Sherudanga beel is largest which is situated to the western side from the Upazila office having $8 \mathrm{~km}$ distance. The beel area usually flooded every year. It remained under water most time of the year. From the month of June to September, the depth of water of the beel becomes 3.5 to $4.5 \mathrm{~m}$. At the dry season (January to April), some portion of the beel was dried.

\section{Data collection Methods}

Field research was done for a calendar year from March 


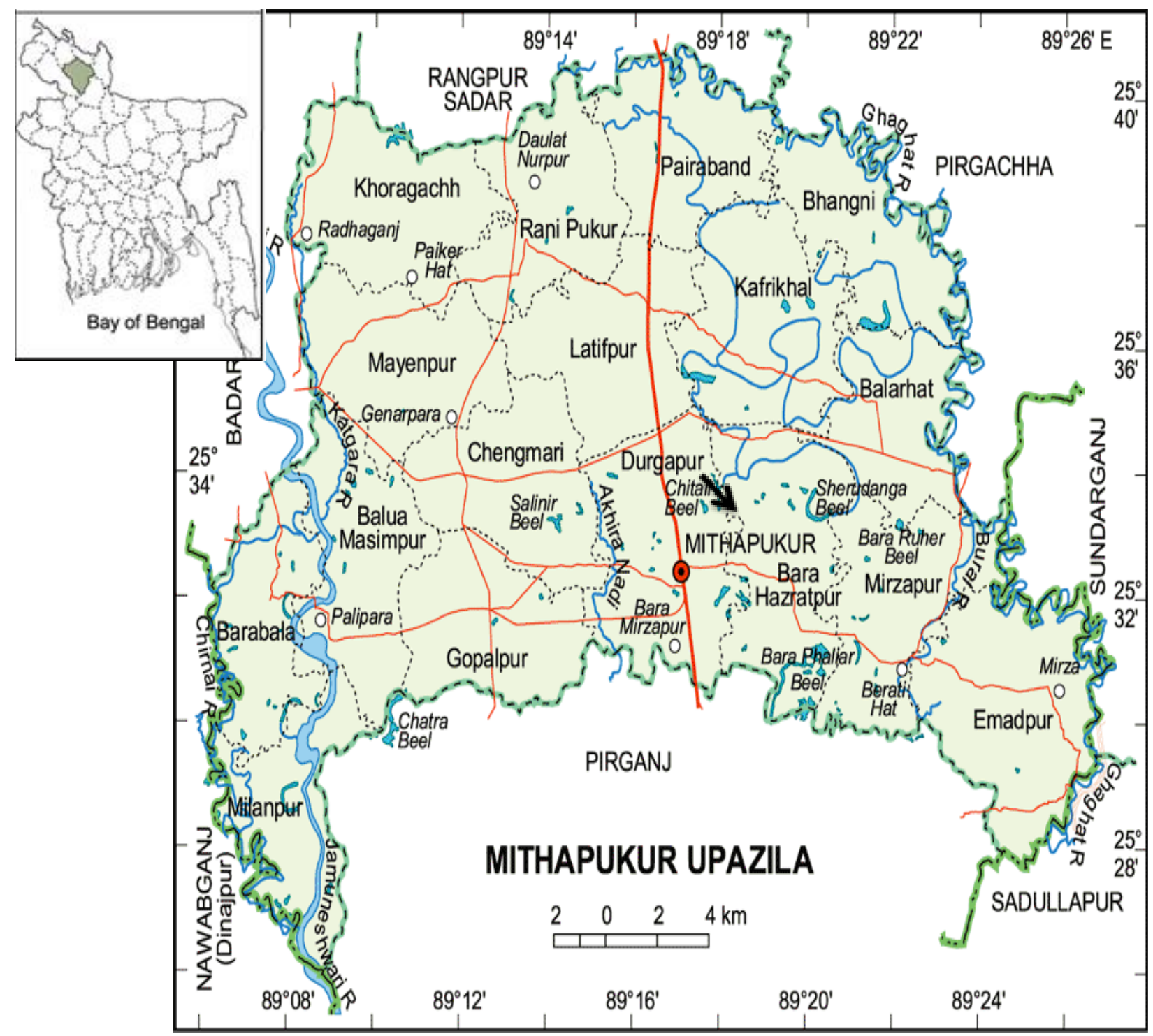

Figure 1. The map of Mithapukurupazila under Rangpur district where the study area, the Sherudangabeel, is indicated by an arrow.Rangpur district is shown in gray color in the inset map picture of Bangladesh. The beel is marked by blue color.

2010 to February 2011. The research was based on both primary and secondary data, comprehensive literature review and extracts of local knowledge and information. Collection of primary data was made by field observations and different methods viz. Questionnaire interview, Questionnaire survey, Participatory Rural Appraisal (PRA) tool (Figure 3). The PRA tool like focus group discussion (FGD) was conducted with members of beel fishing communities including women and children. Survey of operation of different fishing gears, catch trends, survey of fish market adjacent to beel, survey of biological resources of the beel and survey of socioeconomic condition of fishermen was also done. Cross- check interviews were conducted with key informants, such as district and sub-district fisheries officers, researchers, relevant project staff, and non-governmental organization (NGO) workers. At the same time, the researchers directly visited and gathered knowledge about physical environment of the beel fishing practice and household's role as well as livelihood strategy, power relation's socio-cultural norm and institutional, economic and demographic conditions. Secondary data was collected through literature and publication available from Upazila Fisheries Officer, local administration, Water Development Board (WDB), Department of Fisheries (DoF), Bangladesh Fisheries Research Institute (BFRI) 

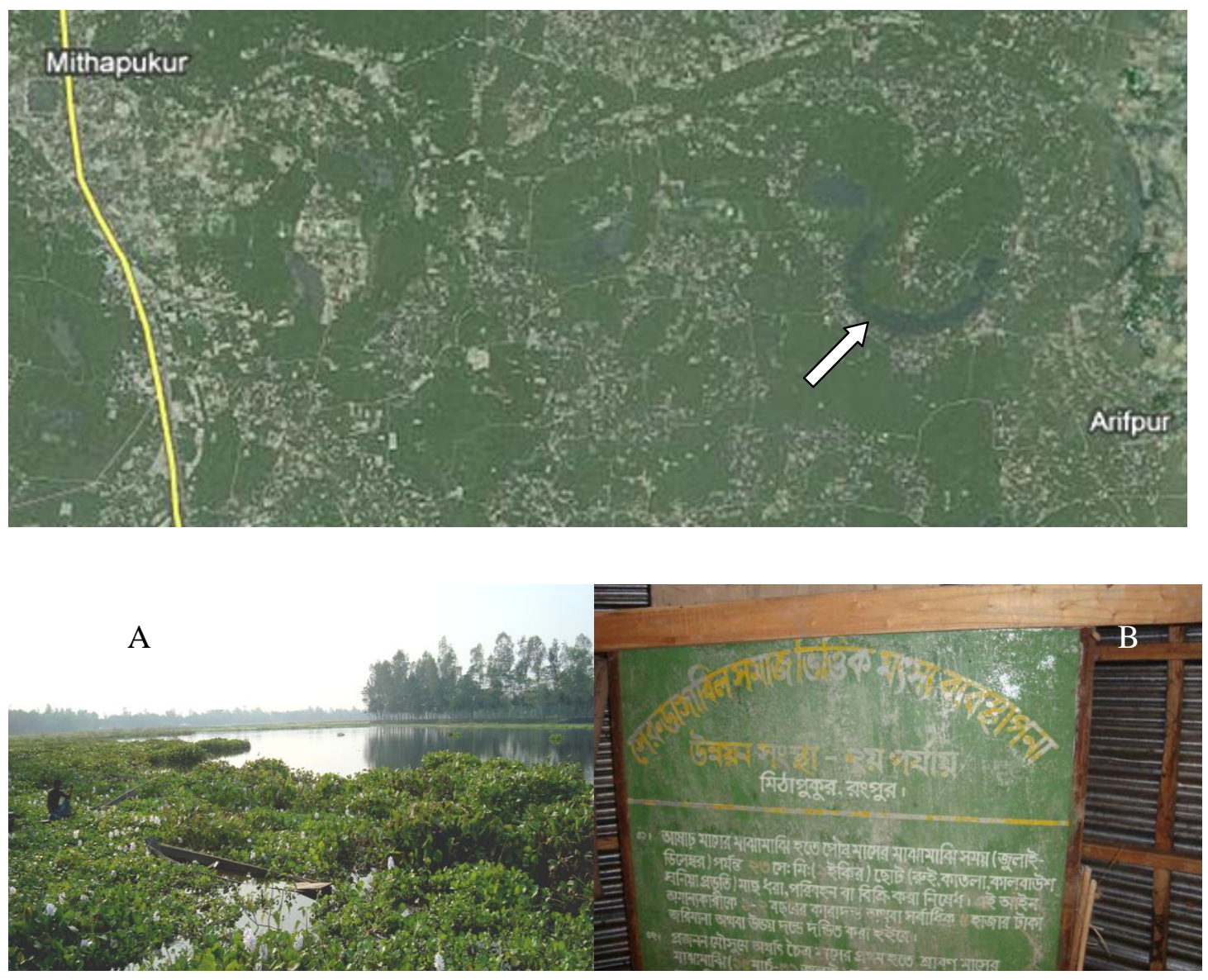

Figure 2. Magnified satellite view of the portion of Mithapukur upazila where Sherudanga beel is indicated by an arrow (upper picture). Photograph was collected from Google Earth. The appearance of the study area (Sherudanga beel) $(A)$ and a board describing the name \& address of the CBFM community in Bengali $(B)$ are shown in the down picture.

and related NGOs. Assistance also taken from quarterly and annual reports of fisheries, reports and books from Community Development and Settlement Program (CDSP) office and books of Bangladesh bureau of statistics.

\section{Sampling of water}

Water samples were collected from six different sites of the beel for plankton abundance study. In every case five liters of water samples were filtered through plankton net of $55 \mu \mathrm{m}$ mesh size. Then the samples were concentrated to a volume of $50 \mathrm{ml}$ and preserved in plastic vials with $5 \%$ formalin. For analysis, a sub-sample at $1 \mathrm{ml}$ was quickly drawn with a wide mouthed pipette and poured into a Sedgewick Rafter counting chamber of $1 \mathrm{ml}$ capacity and organisms were counted as outlined by Boyd (1979). The S-R counting cell was placed under a binocular microscope (Olympus $\mathrm{BH} 2$ with phase contrast facilities; magnification 40x) and the plankton was identified and recorded.

\section{Fish sampling}

Identification of fishes was done through collection of different species directly from fishers, fishing through different types of gears, fishing through enclosure with bana, kua fishing, kata fishing and surveying from local fish markets. Identification of non-piscine species was done simultaneously. Aquatic weeds were collected from the beel and identification was made in the laboratory.

\section{Analysis of findings}

The collected data were coded, summarized and 

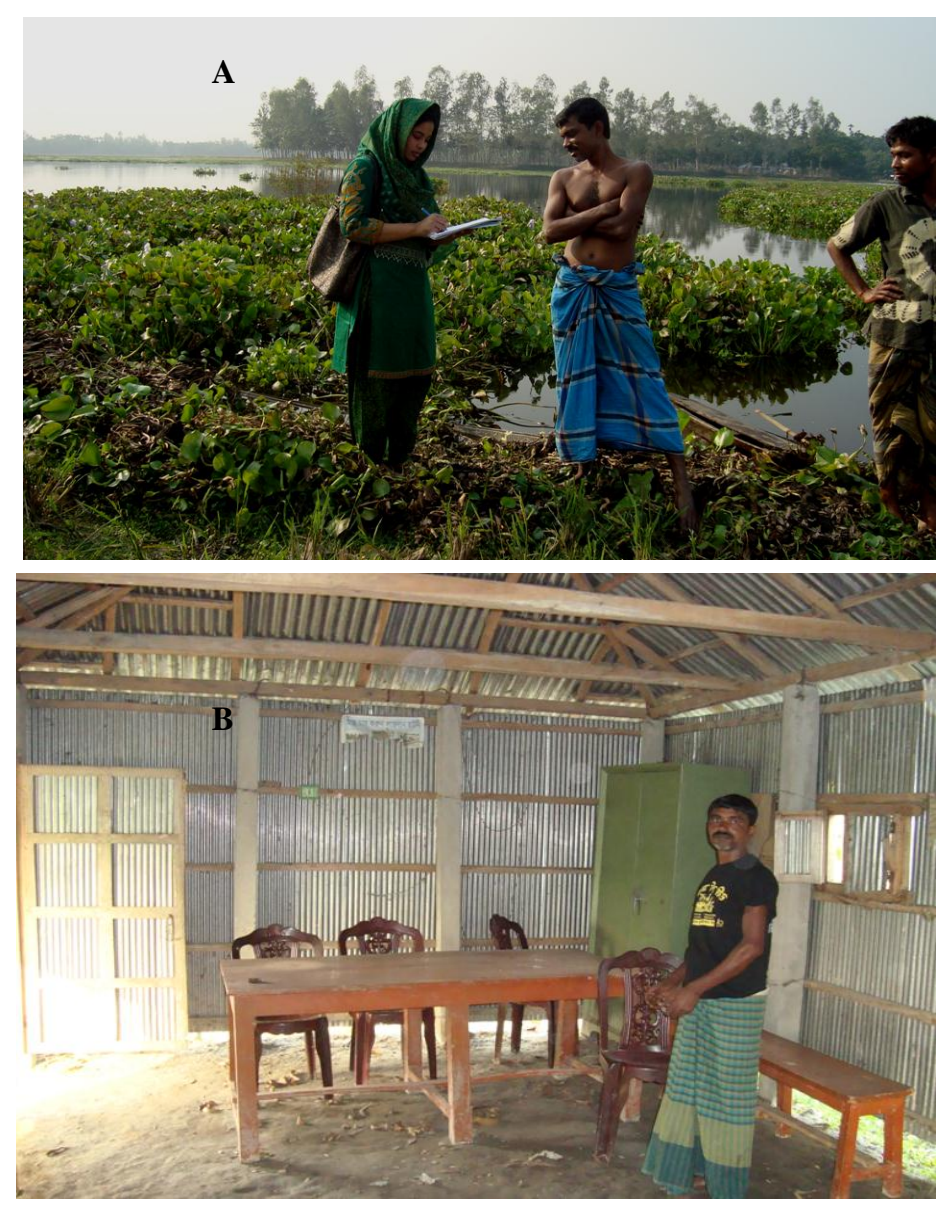

Figure 3. A: Collection of data by questionnaire interview and B: Sherudanga beel community based fisheries management office along with a member of the CBFM committee.

processed for analysis. These data were verified to eliminate all possible errors and inconsistencies by some criteria and standards for evaluation of the overall significance. Tabular technique was applied for the analysis of data by using simple statistical tools like average and percentages. Collected data was analyzed by using Microsoft Excel.

\section{RESULTS}

At the pre-CBFM time in Sherudanga beel community, the livelihood status, socio-economic condition and beel management performance were unpleasant. Anomalies in fish culture and lack of organization and supervision of the beel resulted in reduction of fish production that affected their livelihood. Serudanga beel is being managed since 2000 under the CBFM project which is implemented by the partnership of DoF and BRAC, a non-government organization. With the help of participating NGOs, the community fishermen of the study area formed a beel management committee (BMC) (Figure 4). This committee properly manages the beel by the following continuous process introduced by CBFM system.

\section{Biodiversity of the Sherudanga beel}

Sherudanga beel is rich with fish and other aquatic biodiversity. During the study period, a total of 31 resident species were recorded (Table 1) from the beel of which 21 species were common, 6 rare and 4 species were highly endangered. A total of 9 non-resident species also were recorded of which seven are stocked species and the other two are non-stocked (Table 2). Otherwise, six species were identified as extinct species (Table 3 ). Of the 40 fish species, 12 species belong to the family of 
Table. 1. List of resident species recorded in Sherudanga bee/ during study period.

\begin{tabular}{|c|c|c|c|c|c|}
\hline SI. No. & Family & Local name & $\begin{array}{l}\text { Common name/ } \\
\text { English name }\end{array}$ & Scientific name & Comment \\
\hline 1 & Anabantidae & Koi & Climbing perch & $\begin{array}{l}\text { Anabas testudineus } \\
\text { (Bloch, 1792) }\end{array}$ & common \\
\hline 2 & Anabantidae & khalisha & Goramy & $\begin{array}{l}\text { Colisa fasciatus } \\
\text { (Bloch and Schneider, 1801) }\end{array}$ & Common \\
\hline 3 & Anabantidae & $\begin{array}{l}\text { Ranga } \\
\text { Khalisha }\end{array}$ & Goramy & $\begin{array}{l}\text { Colisa Ialiuis } \\
\text { (Hamilton, 1822) }\end{array}$ & $\begin{array}{l}\text { Highly } \\
\text { endangered }\end{array}$ \\
\hline 4 & Bagridae & Gulsha & Catfish & $\begin{array}{l}\text { Mystus cavasius } \\
\text { (Hamilton, 1822) }\end{array}$ & $\begin{array}{l}\text { Highly } \\
\text { endangered }\end{array}$ \\
\hline 5 & Bagridae & Tengra & Catfish & $\begin{array}{l}\text { Mystus vittatus } \\
\text { (Bloch, 1794) }\end{array}$ & Common \\
\hline 6 & Belonidae & Kakila & Needle fish & $\begin{array}{l}\text { Xenentodon cancila } \\
\text { (Hamilton, 1822) }\end{array}$ & Common \\
\hline 7 & Belonidae & $\begin{array}{l}\text { Lamba } \\
\text { chanda }\end{array}$ & $\begin{array}{l}\text { Elongate } \\
\text { perchlet }\end{array}$ & $\begin{array}{l}\text { Chanda nama } \\
\text { (Hamilton, 1822) }\end{array}$ & Common \\
\hline 8 & Channidae & Taki/ Lati & Snakehead & $\begin{array}{l}\text { Channa punctatus } \\
\text { (Bloch, 1793) }\end{array}$ & Common \\
\hline 9 & Channidae & Shoal & Snakehead & $\begin{array}{l}\text { Channa striatus } \\
\text { (Bloch, 1793) }\end{array}$ & Common \\
\hline 10 & Channidae & Gajar & Giant snakehead & $\begin{array}{l}\text { Channa marulius } \\
\text { (Hamilton, 1822) }\end{array}$ & Common \\
\hline 11 & Channidae & Cheng & Asiatic snakehead & $\begin{array}{l}\text { Channa orientalis } \\
\text { (Bloch and Schneider, 1801) }\end{array}$ & Common \\
\hline 12 & Clariidae & Magur & Catfish & $\begin{array}{l}\text { Clarias batrachus } \\
\text { (Linnaeus, 1758) }\end{array}$ & Common \\
\hline 13 & Clupedae & Chapila & Shad/Herring & $\begin{array}{l}\text { Gudusia chapra } \\
\text { (Hamilton, 1822) }\end{array}$ & $\begin{array}{l}\text { Dominant } \\
\text { resident sp. }\end{array}$ \\
\hline 14 & Clupedae & Kachki & Shad/Herring & $\begin{array}{l}\text { Corica soborna } \\
\text { (Hamilton, 1822) }\end{array}$ & Rare \\
\hline 15 & Cobitidae & Gutum & Loach & $\begin{array}{l}\text { Lepidocephalus guntea } \\
\text { (Hamilton, 1822) }\end{array}$ & Rare \\
\hline 16 & Cyprinidae & Mola & Barb & $\begin{array}{l}\text { Amblypharyngodon mola } \\
\text { (Hamilton, 1822) }\end{array}$ & Common \\
\hline 17 & Cyprinidae & Jatpunti & Spot fin swamp barb & $\begin{array}{l}\text { Puntius sophore } \\
\text { (Hamilton, 1822) }\end{array}$ & Common \\
\hline 18 & Cyprinidae & Tit punti & Barb & $\begin{array}{l}\text { Puntius ticto } \\
\text { (Hamilton, 1822) }\end{array}$ & Common \\
\hline 19 & Cyprinidae & Darkina & Barb & $\begin{array}{l}\text { Rasboradani conius } \\
\text { (Hamilton, 1822) }\end{array}$ & Common \\
\hline 20 & Cyprinidae & $\begin{array}{l}\text { Narkali } \\
\text { Chela }\end{array}$ & Minnow/ Barb & $\begin{array}{l}\text { Salmostoma bacaila } \\
\text { (Hamilton, 1822) }\end{array}$ & Common \\
\hline 21 & Gobiidae & Baila/Bele & Goby & $\begin{array}{l}\text { Glossogobius guiris } \\
\text { (Hamilton, 1822) }\end{array}$ & Common \\
\hline 22 & Heteropneustidae & Shing & Stinging catfish & $\begin{array}{l}\text { Heteropneustes fossilis } \\
\text { (Bloch, 1794) }\end{array}$ & Common \\
\hline 23 & Mastacembelidae & Guchibaim & Striped spiny eel & $\begin{array}{l}\text { Mastacembelus pancalus } \\
\text { (Hamilton, 1822) }\end{array}$ & Common \\
\hline 24 & Mastacembelidae & Shalbaim & Spiny eel & $\begin{array}{l}\text { Mastacembelus armatus } \\
\text { (Lacepède, 1800) }\end{array}$ & Rare \\
\hline
\end{tabular}


Table 1. Contd.

\begin{tabular}{|c|c|c|c|c|c|}
\hline 25 & Mastacembelidae & Tarabaim & Spiny eel & $\begin{array}{l}\text { Macrognathus aculeatus } \\
\text { (Bloch, 1786) }\end{array}$ & Rare \\
\hline 26 & Nandidae & Bheda/Meni & Mud perch & $\begin{array}{l}\text { Nandus nandus } \\
\text { (Hamilton, 1822) }\end{array}$ & Common \\
\hline 27. & Notopteridae & Chital & Feather back & $\begin{array}{l}\text { Notopterus chitala } \\
\text { (Hamilton, 1822) }\end{array}$ & Common \\
\hline 28 & Notopteridae & Foli & Feather back & $\begin{array}{l}\text { Notopterus notopterus } \\
\text { (Pallas, 1769) }\end{array}$ & Rare \\
\hline 29 & Siluridae & $\begin{array}{l}\text { Madhu } \\
\text { pabda }\end{array}$ & Catfish & $\begin{array}{l}\text { Ompok pabda } \\
\text { (Hamilton, 1822) }\end{array}$ & $\begin{array}{l}\text { Highly } \\
\text { endangered }\end{array}$ \\
\hline 30 & Siluridae & Boalipabda & Catfish & $\begin{array}{l}\text { Ompok bimaculatus } \\
\text { (Bloch, 1794) }\end{array}$ & $\begin{array}{l}\text { Highly } \\
\text { endangered }\end{array}$ \\
\hline 31 & Synbranchidae & Kuchia & Mud eel & $\begin{array}{l}\text { Monopterus chuchia } \\
\text { (Hamilton, 1822) }\end{array}$ & Rare \\
\hline
\end{tabular}

Table 2. List of stocked fish species recorded in Sherudanga beel during study period

\begin{tabular}{|c|c|c|c|c|c|}
\hline SI. No. & Family & Local name & $\begin{array}{l}\text { Common name/ } \\
\text { English name }\end{array}$ & Scientific name & Comment \\
\hline 1 & Cyprinidae & Catla & Indian major carp & Catla catla (Hamilton, 1822) & Stocked \\
\hline 2 & Cyprinidae & Rui & Indian major carp & Labeo rohita (Hamilton, 1822) & Stocked \\
\hline 2 & Cyprinidae & Mrigal & Indian major carp & Cirrhinus cirrhosus (Bloch, 1795) & Stocked \\
\hline 4 & Cyprinidae & Silver carp & Chinese carp & $\begin{array}{l}\text { Hypophthalmichthys molitrix } \\
\text { (Valenciennes in Cuvier and Valenciennes, 1844) }\end{array}$ & Stocked \\
\hline 5 & Cyprinidae & Grass carp & Chinese carp & $\begin{array}{l}\text { Ctenopharyngodon idella } \\
\text { (Valenciennes in Cuvier and Valenciennes, 1844) }\end{array}$ & Stocked \\
\hline 6 & Cyprinidae & Carpio & Common carp & $\begin{array}{l}\text { Cyprinus carpio var. Communis } \\
\text { (Linnaeus, 1758) }\end{array}$ & Stocked \\
\hline 7 & Cyprinidae & Bighead carp & Exotic carp & $\begin{array}{l}\text { Aristichthys nobilis } \\
\text { (J. Richardson, 1845) }\end{array}$ & Stocked \\
\hline 8 & Cichlidae & Nilotica & Cichlid fish & $\begin{array}{l}\text { Oreochromis nilotica } \\
\text { (Linnaeus, 1758) }\end{array}$ & Non-stocked \\
\hline 9 & Cichlidae & Tilapia & Cichlid fish & $\begin{array}{l}\text { Oreochromis mossambicus } \\
\text { (W. K. H. Peters, 1852) }\end{array}$ & Non-stocked \\
\hline
\end{tabular}

Table 3. List of the extinct fish species of Sherudanga beel (fishers mentioned the name which were present before now have been extinct).

\begin{tabular}{llllll}
\hline SI. No. & Family & Local name & Common name/ English name & Scientific name & Comment \\
\hline 1 & Belonidae & Ek-thota & Wrestling half beaks & $\begin{array}{l}\text { Dermogenys pusilla } \\
\text { (Kuhl \& van Hasselt, 1823) }\end{array}$ & $\begin{array}{l}\text { Locally extinct } \\
\text { Chaca chaca } \\
\text { (Hamilton, 1822) }\end{array}$ \\
2 & Chacidae & Chaka & Indian chaca & $\begin{array}{l}\text { Puntius sarana } \\
\text { (Hamilton, 1822) }\end{array}$ & Locally extinct \\
3 & Cyprinidae & Sarputi & Olive barb & $\begin{array}{l}\text { Rohtee cotio (Day, 1878) } \\
\text { Chela laubuca } \\
\text { (Hamilton, 1822) }\end{array}$ & Locally extinct \\
4 & Cyprinidae & Dhela & Cotio & $\begin{array}{l}\text { Mystus aor } \\
\text { (Hamilton, 1822) }\end{array}$ & Locally extinct \\
5 & Cyprinidae & Kashkhaira & Indian glass barb & Locally extinct \\
\hline
\end{tabular}


Table 4. List of planktons with their generic and family name recorded from the beel

\begin{tabular}{llll}
\hline Class name & Genus & Class name & Genus \\
\hline Phytoplankton & & Dipodascaceae & Coccidiascus \\
Euglenophyceae & Euglena & Micractiniaceae & Golenkenia \\
& Ankistrodesmus & Chlorella & Cymbellaceae \\
& Cosmarium & Selenastraceae & Monoraphidium \\
& Gonadojygon & Tabellariaceae & Tabellaria \\
Pediastrum & Biddulphiaceae & Biddulphia \\
Chlorophyceae & Tetradron & Stephanodiscaceae & Cyclotella \\
& Ulothrix & Nostocaceae & Anabaena \\
Cyanophyceae & Oscillatoria & Cocconeidaceae & Coconeis \\
Naviculaceae & Navicula & Chaetophoraceae & Pleurococcus \\
Zooplankton & & & \\
Monogononta & Asplanchna & Synuraceae & Mallomonas \\
Maxillopoda & Cyclops and Sida & Coscinodiscophyceae & Fragilaria \\
\hline
\end{tabular}

Cyprinidae, 4 species belong to the family of Channaidae, 3 species belong to the family of Cobitidae, Anabantidae and Mastacembelidae each, 2 species belong to Bagridae, Clupedae, Belonidae, Siluridae, Notopteridae, and Cichlidae families each and only 1 species belong to Clariidae, Gobiidae, Cobitidae, Heteropneustidae, Nandidae, and Synbranchidae family each.

The stocked species were catla (Catla catla), rui (Labeo rohita), silver carp (Hypophthalmichthys molitrix), mrigel (Cirrhinus cirrhosus), carpio (Cyprinus carpio), grass carp (Ctenopharyngodon idella) and bighead carp (Aristichthys nobilis). Moreover, two non-stocked and non-resident species found include nile tilapia (Oreochromis niloticus) and mozambique tilapia (Oreochromis mossambicus). Of the resident species, 21 species were common and most dominant of them includes Puntius sophore, Puntius ticto, Channa punctatus, Channa striatus, Mystus vittatus, Clarias batrachus, Mastacembelus armatus, Heteropneustes fossilis, Wallago attu, Macrobrachium lamerrii, and Macrobrachium malcolmsonii, 6 were rare including Corica soborna, Lepidocephalus guntea, Mastacembelus armatus, Macrognathus aculeatus, Notopterus notopterus, and Monopterus chuchia, 4 were highly endangered including Colisa laliuis, Mystus cavasius, Ompok pabda, and Ompok bimaculatus, and 6 were extinct from the beel including Darmogenys pussilus, Chaca chaca, Puntius sarana, Rohtee cotio, Chela laubuca, and Mystus aor.

The non-piscine biodiversity of Sherudanga beel comprises 2 species of prawn including Macrobrachium lamerii and Macrobrachium malcolmsonii, 6 species of molluscs including Pila globosa, Planorbis sp., Viviparus bengalensis, Melanoides tuberculatus, Lamillidens marginalis and Corbiculata sp., 6 species of arthropods (aquatic insects) including Potamon sp., Belostoma sp., Abedus sp., Ranatra sp., Nepa sp., and Gerirs sp., 4 species of amphibians including Euphlyctis cyanophlyctis, Hoplobatra chustigerinus, Rhacophorus leucomystax and Bufomelanos tictus. Among 4 species of reptiles, two species of bivalves Lamillidens marginalis and Corbicu lata sp. and in reptiles Kachuga tecta (Kochchop) were abundant before but very rare or highly endangered at present.

Other than fish diversity, following type of planktons were observed in the study area including Navicula, Pleurococcus, Cyclotella, Anabaena, Gonadojygon, Oscillatoria, Chlorella, Pediastrum, Euglena, Ulothrix, Fragellaria, Asplanchna, Coconeis, Monoraphidium, Tabellaria, Biddulphia, Sida, Tetradon, Coscinodiscus, Nitzchia, Cyclops, Ankistrodesmus, Cosmarium, Golenkenia, Mallomonas and Cymbella (Table 4). Moreover, rich aquatic plant diversity were also observed including Eichhornia crassipes, Pistia stratiotes, Lemna minor, Azolla pinnata, Nymphaea rubra, Nymphaea nouchali, Nymphaea lotus, Nelumbo nucifera, Vallisneria spiralis, Potamogeton sp., Ipomoea fistulosa, Leersia hexandra, Ipomoea aquatic, Marsilea quadrifolia in the studied beel.

In this study, average fish production for one year was calculated from the cumulative data of large harvest and 


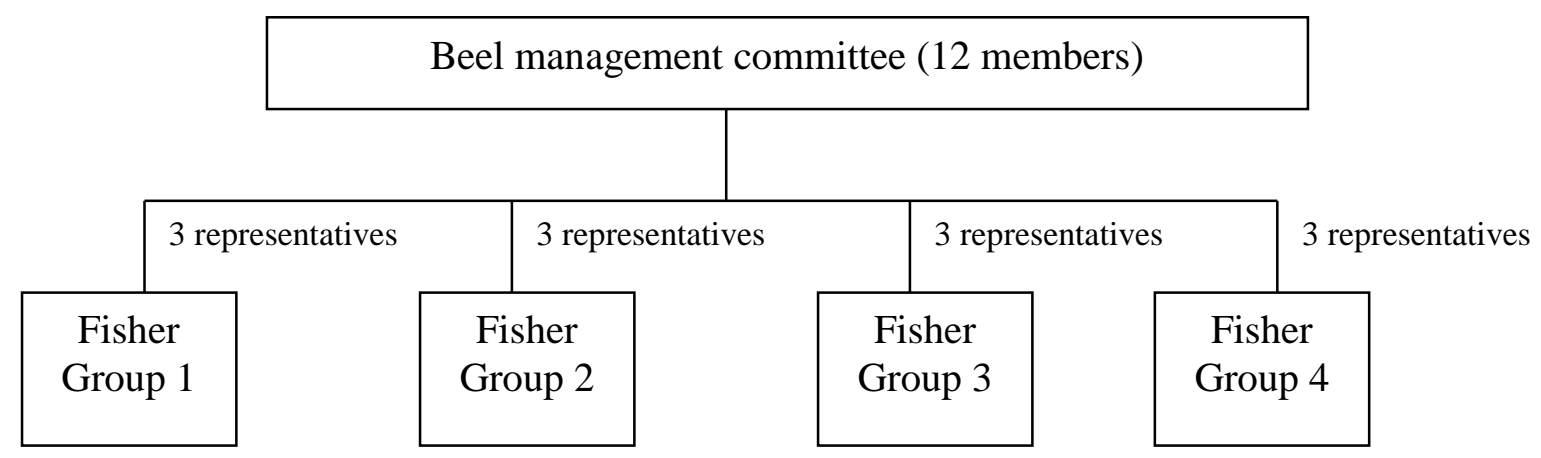

Figure 4. Presentation of the structure of the beel management committee (BMC).

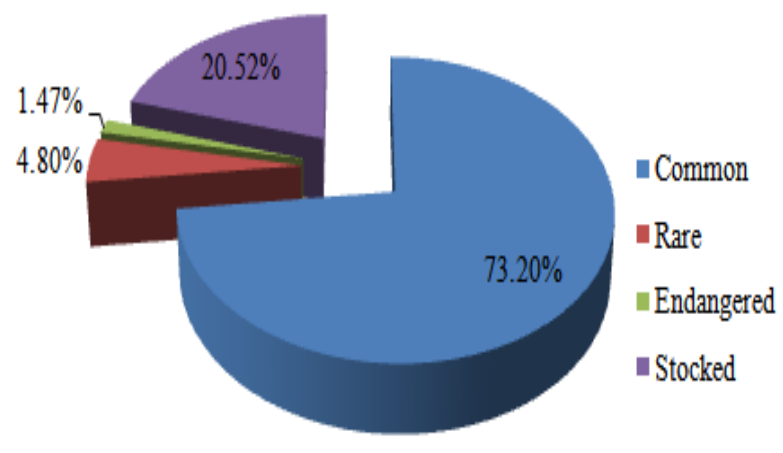

A

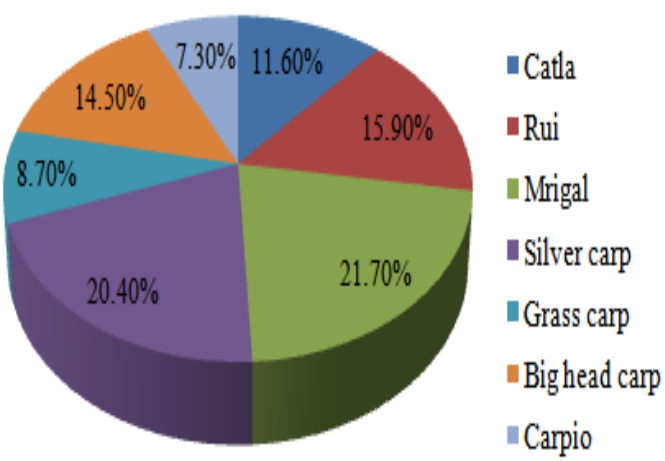

B

Figure 5.Contribution of the fish groups to the net production. A. Contribution of the dominant resident species (common, rare and endangered) and non-resident (stocked) species of fishes; B. Species wise contribution of the stocked fishes to the yearly net fish production obtained from the studied beel in the year 2011 .

daily fish catch. Production of resident fish species of the beel were $9600 \mathrm{~kg}$, on the other hand, gross yield of stoked fishes were $2480 \mathrm{~kg}$ in 2011. Net yields of the stocked fishes were calculated by the gross yield of the harvested carp's yields minus the weight of the fingerlings stocked. Net yields of stocked fishes were $2200 \mathrm{~kg}$ as the weight of the carp fingerlings was $280 \mathrm{~kg}$. Thus, net production of fishes was $11800 \mathrm{~kg}$ in the year 2011. A total of 46 fish species were recorded from the studied water body during study period. Among the most dominant resident species, 15 common species (mostly Puntius sophore, Puntius ticto, Channa punctatus, Channa striatus, Mystus tengra, Mastacembelus armatus, Macrobrachium malcolmsonii) represented nearly $73.2 \%$ of the total catch, while, rare and highly endangered species represented about $4.8 \%$ and $1.47 \%$, respectively. On the other hand production of stocked fish species represented about $20.52 \%$ of the total catch for the year 2011 (Figure 5).

\section{Biological Resource Management}

\section{Stocking}

During flooding small indigenous fish species come with the flood water by different channel in the beel and these fishes are known as resident fish. The other is nonresident or stocked fishes which are necessary to stock in the bee/ with those of non-stocked fishes during stocking. During study period of the year 2010 in the beel, $280 \mathrm{~kg}$ fish fingerlings (4-6" in size) were stocked, where the number of fish fingerlings was about 6200 . The fish species were rui (Labeo rohita), catla (Catla catla), mrigal 
Table 5. Stocking of the non-resident fish fingerlings in 2010 at the beel (area of the beel is about 80 acre, while about 500 acre during flooding).

\begin{tabular}{llccccc}
\hline SI. No. & Species & Size & Stocking No. & Stocking weight (kg) & Stocking value (USD kg-1) & Total USD $^{-1.4}$ \\
\hline 1 & Labeo rohita & $4-5^{\prime \prime}$ & 1000 & 40 & 1.4 & 56.2 \\
2 & Catla catla & $5-6 "$ & 800 & 40 & 1.6 & 63.86 \\
3 & Cirrhinus cirrhosus & $4-5 "$ & 1200 & 40 & 1.15 & 45.98 \\
4 & Cyprinus carpio & $5.5-6.5^{\prime \prime}$ & 600 & 40 & 1.92 & 76.63 \\
5 & Ctenopharyngodon idella & $5-6 "$ & 600 & 40 & 0.96 & 63.86 \\
6 & Hypophthalmichthys molitrix & $5-6 "$ & 1200 & 40 & 0.83 & 38.32 \\
7 & Hypophthalmichthys nobilis & $4-5 "$ & 800 & 40 & - & 33.21 \\
Total & & $\mathbf{6 2 0 0}$ & $\mathbf{2 8 0}$ & & $\mathbf{3 7 8 . 0 6}$ \\
\hline
\end{tabular}

(Cirrhinus mrigala), grass carp (Ctenopharyngodon idella), silver carp (Hypophthalmichthys molitrix), bighead carp (Aristichthys nobilis) and common carp (Cyprinus carpio). Fish fingerlings were released during July, 2010 and harvested on March, 2011. The stocking density of the fingerlings in the beel for the year 2010 is summarized in the Table 5 .

\section{Nursery management}

The BMC collected fish fry of selected species (Labeo rohita, Catla catla, Cirrhinus cirrhosus, Hypophthalmichthys molitrix, Hypophthalmichthys nobilis, Ctenopharyngodon idella and Cyprinus carpio) and managed them in a nursery pond. Two nursery ponds were used at the corner of the beel having an area of 20 and 23 decimal. They collected fish fry from nearest government hatchery.

\section{Establishment of Sanctuary}

To overcome any endangered situation, community fishermen established two sanctuaries in this beel. Establishment of aquatic sanctuary is one of the effective tools for conserving fish stock, preserving biodiversity and increasing fish production. After the establishment of the sanctuary, fishermen of the studied beel reported a dramatic change of fish species such as Nandus nandus, Channa marulius, Barbodes gonionotus which were in endangered condition during pre-CBFM period become abundant in their density resulting the improvement of fish production and increment of fish biodiversity as well as production of Labeo rohita, Catla catla and Cirrhinus cirrhosus become elevated than the before.

\section{Maintenance of fishing banned period}

For regular recruitment of resident species, BMC maintains a minimum three months of fishing banned period (closed fishing season) during breeding season (June-September). At that time BRAC provided loans for the fishermen.

\section{Implementation of fish act}

Fishers got training from BRAC to protect environment and now they are more aware for protecting their own resources. Various types of fishing gears were found to operate in the study area. They were mostly traditional type and some of them were unique for the particular locality. From the survey it was found that nets, traps and wounding gears were operated by the fishermen in Sherudanga beel (Table 6). Besides these, fishermen also practiced dewatering and hand picking fisheries. Due to the vastness of the water body nets are operated more frequently. BMC discourage to catch undersized stock fish and strictly prohibited use of destructive fishing gear (current jal). In case of any violation of rules, BMC take necessary steps as may impose fine and even cancellation of membership.

\section{Fish marketing channel}

The price of fish depends on market structure, species, quality, size and weight. All traders in markets made a considerable amount of profit. However, concerns arises about the sustainable system of market due to higher transport costs, poor road and transport facilities, poor supply of ice, lack of money and poor institutional support. It was observed that, three types of fish marketing channel exist in the studied area. These were: i) Fishermen $\rightarrow$ Consumer ii) Fishermen $\rightarrow$ Retailer $\rightarrow$ Consumer iii) Fishermen $\rightarrow$ Arotdar $\rightarrow$ Wholesaler $\rightarrow$ Retailer $\rightarrow$ Consumer. Results of the present study indicated that $15 \%$ of the fishermen directly sold their fish to the consumers, while, $37 \%$ of them disposed their fish to the retailer and $48 \%$ of the fishermen handed over their fish to the wholesaler. 
Table 6. Different kinds of fishing gear used in Sherudanga beel

\begin{tabular}{ll}
\hline Group name & Name of gears \\
\hline \multirow{2}{*}{ Nets } & $\begin{array}{l}\text { Lift net (Dharma jal) } \\
\text { Cast net (Jhakijal) } \\
\text { Gill net (Current jal) } \\
\end{array}$ \\
$\begin{array}{l}\text { Push net (Thelajal) } \\
\text { Seine net (Berjal) }\end{array}$ \\
Traps & Bair (Darki) \\
Wounding gears & $\begin{array}{l}\text { Hook (Borshi) } \\
\text { Koch, Ekkata etc. }\end{array}$ \\
\hline
\end{tabular}

\section{Socio economic condition of the fishermen}

Socio economic condition of the fishermen also studied to know the impact of CBFM approach because fishers are one of the most vulnerable communities in Bangladesh. At present, most of the fishermen have middle sized family (5-6 members). Majority (37.5\%) of fishermen had primary level education compared to $27.5 \%$ and $16.3 \%$ having secondary and above secondary level education respectively, while about $18.75 \%$ of them could sign their names only. The prevalence of unconstructed house was the highest $(77.5 \%)$ among the fishermen, while a few of them $(22.5 \%)$ had semi-constructed house. Drinking water facilities, use of sanitary latrines and prevalence of different diseases was observed in good condition. The annual income of the fishermen varied from USD 459.792 to 753.55 . Above three fourth $(68.75 \%)$ of the fishermen had medium income, while the proportion of small and large income earning fishermen are $12.5 \%$ and $18.75 \%$, respectively. Thus the overwhelming majority of the fishermen had medium to large income which might have been helpful for the management of their families and the beel. As regards to receipt of credit facilities more than half $(56.25 \%)$ of the fishermen indicated that they had received credit from different sources such as banks (33.33\%), NGOs (22.22\%), money lenders $(22.22 \%)$, relatives and friends $(11.12 \%)$ and others $(11.12 \%)$. The rest $43.75 \%$ of them said that they either did not require any credit or they did not get any credit. Most of the families of the fishermen had comparatively fairly well food security status. Dramatic awareness has been achieved after implementation of CBFM approach. Women participation in beel management activities found in progress. Women help in net making, fish harvesting, fish marketing and involved in decision making processes which led to a dramatic social change across Bangladesh (Figure 6). The CBFM has had considerable impact on poverty reduction and has improved food security. Before the CBFM, more than half of the households were classified as poor. The figure has now decreased to less than half. Although the fishermen of Sherudanga beel enjoying CBFM's positive impact on reducing poverty, improvement of natural resources by sustainable management of the resources but they are facing some problems during management of the beel including unavailability of quality seeds at reasonable prices and at due time, theft of fish by miscreants, recurring flooding of the beel, political pressure, occupying the beel edges by the nearby land owner during dry season, inadequate monitoring from fisheries officer, shortage of capital and inadequate credit facilities of the society etc.

\section{DISCUSSIONS}

After the implementation of CBFM system in the beel the dramatic changes has occurred regarding various aspects of the beel and beel fishery. Sherudanga beel is rich in its fish diversity, where 7 stocked, 31 resident and 6 extinct species were identified. During study period, a total number of 40 species of fish, 2 species of prawn, 6 species of molluscs, 6 species of arthropods, 4 species of amphibia and 3 species of reptiles were recorded in Sherudanga beel. Some species, which were highly endangered, found available during study period: For example, foli (Notopterus notopterus), boali pabda (Ompok bimaculatus), bheda/meni (Nandus nandus), baila/bele (Glossogobius guiris) etc. that might be due to good environment, sanctuary establishment as well as good management system for the beel. The common resident species like guizza (Mystus seenghala), and vedha (Nandus nandus) was rare before. At present these two species are abundant due to the biological and social management of the beel. In case of floral diversity, Eichhornia crassipes was most common in the beel periphery. Besides, a huge diversity of planktons was observed in the studied beel which were the primary food for the fish. Fishers applied urea to increase primary food production. Ahmed et al. (2004) recorded a total of 52 fish species belonging to 36 genera under 20 families and 1 species of prawn during the study period in Shakla beel under Brahamanbaria district. Siddiquee (2001) recorded a total of 14 non-resident fish and 43 resident species were identified of which 30 were common, 9 rare and 5 were highly endangered in Rajdhala beel under Netrokona district. Trivedi and Das (2006) reported that the phytoplankton and zooplankton composition, total count and species diversity in the Kulia beel, Nadia district, West Bengal, India, were determined to assess the ecological status of this floodplain wetland. Results showed that among phytoplankton, Cyanophyceae and Euglenophyceae were observed, while Rotifera, Cladocera and Copepoda were observed among zooplankton. CBFM maintained rules and regulations that is why fish production increased manifold in the beel. In the studied beel the weight of harvested fishes was 8.85 


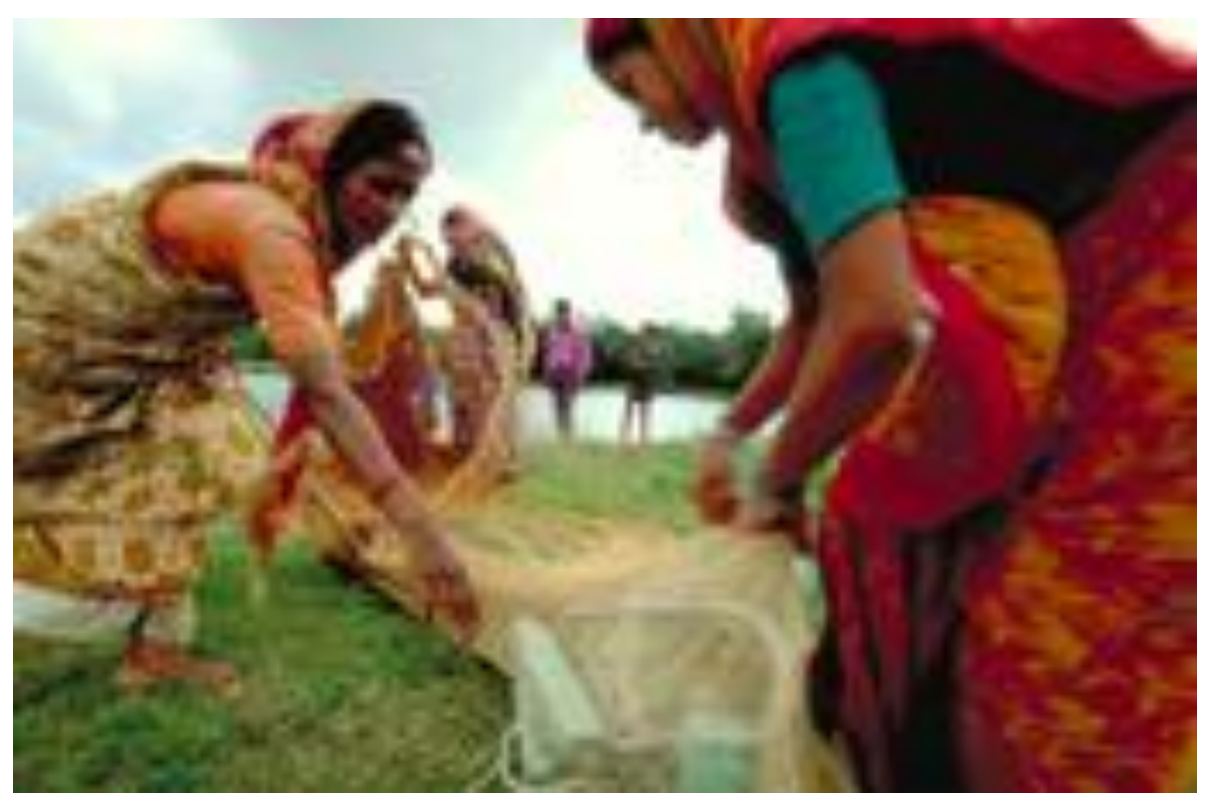

Figure 6. Women participation in Sherudanga beel

times higher than the weight of fish fingerlings released in the beel. The less production of stocked fish on the previous time in the bee/ was mainly due to less stocking of fish fingerlings, poor growth of fish and inappropriate management in fish culture. According to Shahjahan et al (2001) absence of proper management policy is one of the main reason of declining fisheries resources from open water of Bangladesh. Appropriate management policy is essential to increase fish production as well as improvement of socio-economic condition of fishing community. After the formation of CBFM in the Sherudanga beel, the water body was well managed by the community by managing nursery management, weed management, quality brood fish, proper way of fish harvesting etc. CBFM approach encouraged fishers to follow fish act to protect environment and to increase awareness for protecting their own resources. CBFM discourage to catch undersized stock fish and strictly prohibited use of destructive fishing gear.

Impact of CBFM on the livelihood of social groups in the studied area also assessed to know the economic impact. It was found that, the fishermen of the beel lived a very miserable life due to limited income before management of the beel. They had no education and usually they had food deficit. Their housing condition was also miserable and they did not maintain proper health and sanitation. After the formation of CBFM, they could have legal access to the beel and due to proper management of the beel, they are more organized. They can easily contact Upazila Fisheries Officer (UFO), Upazila Nirbahi Officer (UNO) and other administrative persons for their own interest. These indicate the direct impacts of CBFM on fishermen's life. Literacy rate was very poor in the fisher community before starting of the beel management. But at present the literacy rate has reached a satisfactory level. Effective literacy percentage of the fishermen of the study area was $81.25 \%$ which was higher than the national average. Fewer children between the age 5 to14 going to school in the past were fewer compared to now. But due to the social awareness and increased income through beel management, more than $95 \%$ of the children were found going to school and housing condition of most of the fisher's family has improved.

For the success of CBFM, fishermen must regard the resources as their own. When fishermen consider the fish stocks as their property, they will adopt a more positive attitude to conservation and management measures (FAO, 1984). The community fishermen were inspired after intervention of community based fish culture in the studied beel. To raise their income from fish culture in this water body, it is needed to practice of new such technology in future. Under CBFM approach, fishermen received technical training regarding fish culture in open water body. Community fishers were motivated to continue this approach in the following years and to establish a sanctuary for preserving brood fish of small indigenous fish species.

Two key lessons emerge from this approach to improving natural resource management. First, although improved management of the beel results in a substantial increase in fish production, poverty can be reduced only if control of the beel is in the hands of genuine fishers. Second, the support of district administrative and fishery 
officials, as well as NGO facilitators, are essential in helping the group to reduce the influence of local or external power elites and in establishing norms of cooperative behavior and democratic functioning of beel fishing groups.

\section{Conclusion}

The results of this study indicated that the livelihood and socio-economic conditions of the fishermen improved than before the implementation of CBFM approach. The beel is a promising source for different kinds of native fish species as well as a crucial venue for improvement of socio-economic status of fishermen. This approach benefits the landless poor fishers by involving wide range of original fishermen in fish culture activities. Thus it ensures raise in average household incomes by $13 \%$ and average fish consumption of participating fishermen increased by $23.70 \%$ over the project period and helps in better sharing of benefits among the fishermen. Increasing access to various credit sources such as Grameen bank, ASA, BRAC and local co-operatives, suggest that the best approach may be to create strong links between fisher groups and existing NGOs. Fishers have changed their attitude and have greater awareness of fisheries rules and compliance through community based co-management policy and enforcement of Fish Regulation Act-1950. It is expected that CBFM approach will be able to restrict exploitation of the poor original fishers by money lender and other elite influential in this open water bodies by strengthening the bonding within fishermen society and by making them commercially strong.

\section{CONFLICT OF INTEREST}

The authors declare that they have no conflict of interest.

\section{References}

Ahmed, K. K. U., Hasan, K. R., Ahmed, S. U., Ahmed, T., \& Mustafa, M. G. (2004). Ecology of Shakla beel (Bramhmonbaria). Bangladesh Journal of Fisheries 9,101110.

Ali, M. Y. (1997). Fish, water and people: Reflection on inland open water fisheries resources of Bangladesh. University press Ltd. Dhaka, Bangladesh. 127p.

Berkes, F., Feeny, D., McCay, B. J., \& Acheson, J. M., (1998). The benefit of the common. Nature 340, 91-93.

FAO (1984) Report of consultation on the regulation of fishing effort (fishing mortality). FAO Fisheries Report No. 289, Rome. 1993.

Haque, A. K. M. A, Middendorp, H. A. J., \& Hasan, M. R., (1999). Impact of carp stocking on the abundance and biodiversity of non-stock indigenous fish species in culture based fisheries: A case study of from oxbow lakes. In: Middendorp, H. A. J., Thompson, P.M., \& Pomeroy, R. S. (eds.) Sustainable Inland Fisheries Management in Bangladesh.ICLARM Corf. Proc. 58, 141-148.

Ostrom, E., (1990). Governing the Commons: The Evolution of Institutions for Collective Action. Cambridge University Press, Cambridge.

Pomeroy, R. S., \& Berkes, F. (1997). Two to tango: The role of government in fisheries co management. Marine Policy, 21, 465-480.

Sajise, P. (1995). Community-based resource management in the Phillipines: perspective and experiences. A paper presented at the Fisheries co-management Workshop at North sea center, 29-31 may, Hirtshals, Dernmark.

Shahjahan, M., Miah, M. I., Haque, M. M., (2001). Present status of fisheries in the Jamuna river. Pak. J. Biol. Sci., 4(9), 1173-1176.

Siddiquee, M. J. A. (2001). Biological and social management of Rajdhalabeel at Netrokona district and its impacts on Biodiversity and poverty alleviation. MS Thesis, Department of Fisheries Management, Bangladesh Agricultural University. $78 p$.

Trivedi, R. K, \& Das, S. K., (2006). Plankton as a tool for the ecological assessment of a floodplain wetland. Department of Fisheries Environment, Faculty of Fisheries Science, W.B.U.A.F.S. J. Inter. acad. 10(4), 573-577. 